9 Stowkowy J, Addington D, Liu L, Hollowell B, Addington J. Predictors of disengagement from treatment in an early psychosis program. Schizophr Res 2012; 136: 7-12.

10 Turner M, Smith-Hamel C, Mulder R. Prediction of twelve-month service disengagement from an early intervention in psychosis service. Early Interv Psychiatry 2007; 1: 276-81.

11 Conus P, Lambert M, Cotton S, Bonsack C, McGorry PD, Schimmelmann BG. Rate and predictors of service disengagement in an epidemiological firstepisode psychosis cohort. Schizophr Res 2010; 118: 256-63.

12 Albert N, Melau M, Jensen $\mathrm{H}$, Emborg C, Jepsen JRM, Fagerlund B, et al. Five years of specialised early intervention versus two years of specialised early intervention followed by three years of standard treatment for patients with a first episode psychosis: randomised, superiority, parallel group trial in Denmark (OPUS II). BMJ 2017; 356: j1015

13 Bertelsen $\mathrm{M}$, Jeppesen $\mathrm{P}$, Petersen $\mathrm{L}$, Thorup $\mathrm{A}$, Øhlenschlæger J, le Quach $\mathrm{P}$ et al. Five-year follow-up of a randomized multicenter trial of intensive early intervention vs standard treatment for patients with a first episode of psychotic illness. Arch Gen Psychiatry 2008; 65: 762.

14 Chang WC, Chan GHK, Jim OTT, Lau ESK, Hui CLM, Chan SKW, et al. Optimal duration of an early intervention programme for first-episode psychosis: randomised controlled trial. Br J Psychiatry 2015; 206: 492-500.

15 Chang WC, Kwong VWY, Lau ESK, So HC, Wong CSM, Chan GHK, et al. Sustainability of treatment effect of a 3-year early intervention programme for first-episode psychosis. Br J Psychiatry 2017; 211: 37-44.

16 Leclerc E, Noto C, Bressan RA, Brietzke E. Determinants of adherence to treatment in first-episode psychosis: a comprehensive review. Rev Bras Psiquiatr 2015; 37: 168-76.

17 Kreyenbuhl J, Nossel IR, Dixon LB. Disengagement from mental health treatment among individuals with schizophrenia and strategies for facilitating connections to care: a review of the literature. Schizophr Bull 2009; 35: 696-703.

18 Kirkbride JB, Hameed Y, Ankireddypalli G, Ioannidis K, Crane CM, Nasir M, et al. The epidemiology of first-episode psychosis in early intervention in psychosis services: findings from the social epidemiology of psychoses in East Anglia [SEPEA] study. Am J Psychiatry 2016; 174: 143-53.
19 McGuffin P, Farmer A, Harvey I. A polydiagnostic application of operational criteria in studies of psychotic illness: development and reliability of the OPCRIT system. Arch Gen Psychiatry 1991; 48: 764-70.

20 Williams J, Farmer AE, Ackenheil M, Kaufmann CA, McGuffin P. A multicentre inter-rater reliability study using the OPCRIT computerized diagnostic system. Psychol Med 1996; 26: 775-83.

21 StataCorp. Stata Statistical Software version 13. 2013

22 Doyle R, Turner N, Fanning F, Brennan D, Renwick L, Lawlor E, et al. Firstepisode psychosis and disengagement from treatment: a systematic review. Psychiatr Serv 2014; 65: 603-11.

23 Lal S, Malla A. Service engagement in first-episode psychosis: current issues and future directions. Can. J. Psychiatry 2015; 60: 341-5.

24 Anderson KK, Fuhrer R, Schmitz N, Malla AK. Determinants of negative pathways to care and their impact on service disengagement in first-episode psychosis. Soc Psychiatry Psychiatr Epidemiol 2013; 48: 125-36.

25 Craig TKJ, Garety P, Power P, Rahaman N, Colbert S, Fornells-Ambrojo M, et al. The Lambeth Early Onset (LEO) Team: randomised controlled trial of the effectiveness of specialised care for early psychosis. BMJ 2004; 329: 1067

26 Schimmelmann BG, Conus $\mathrm{P}$, Schacht M, Mcgorry $\mathrm{P}$, Lambert M. Predictors of service disengagement in first-admitted adolescents with psychosis. J Am Acad Child Adolesc Psychiatry 2006; 45: 990-9.

27 Gafoor R, Nitsch D, McCrone P, Craig TKJ, Garety PA, Power P, et al. Effect of early intervention on 5-year outcome in non-affective psychosis. Br J Psychiatry 2010; 196: 372-6.

28 Tait L, Birchwood M, Trower P. A new scale (SES) to measure engagement with community mental health services. J Ment Heal 2002; 11: 191-8.

29 Tetley A, Jinks M, Huband N, Howells K. A systematic review of measures of therapeutic engagement in psychosocial and psychological treatment. J Clin Psychol 2011; 67: 927-41.

30 Gronholm PC, Thornicroft G, Laurens KR, Evans-Lacko S. Mental health-related stigma and pathways to care for people at risk of psychotic disorders or experiencing first-episode psychosis: a systematic review. Psychol Med 2017; 47: $1867-79$

\title{
No account of post-traumatic recurrent dreams in the second century AD
}

\section{Greg Wilkinson}

Artemidorus, ${ }^{1}$ whose books encompass a system of dream interpretation in the second century AD, was overwhelmed by the vast amount of research involved in the work and by the abundance of material. He adds that not only has he taken special pains to procure every book on the interpretation of dreams, but he has consulted for many years with the diviners of the marketplace. Although trauma is likely to have been highly prevalent, Artemidorus gives no account of post-traumatic dreams. This suggests that these dreams were not a feature of his wide reading, consultation and practice, but rather that they are a product of later cultures:

'Recurrent dreams, if they appear at small intervals and continually, should be considered as always having the same meaning. And because they are seen frequently, we should be more attentive to them and place greater faith in them. As a matter of fact, whenever we have something important to say, we usually say it frequently. Similarly, then, our mind also presents these dreams frequently either because it is prophesying matters that are serious, meaningful and not of secondary importance or because it has begun to see them long before their fulfilment and continues to see them uninterruptedly.

But whenever the intervals between recurrent dreams are long, one must realise that the dreams will mean different things at different times. For just as the same dream comes true in different ways for each person who has seen it because the circumstances of all men are not the same, so too the same dream when seen at different times by one person will come true in different ways because he himself does not always remain in the same circumstances.

For example, a man dreamt that he lost his nose. He was a perfume dealer at the time. Since he did not have a nose in the dream, he lost his store and stopped selling perfumes. For he no longer possessed the means to test his perfumes and it was obvious that he would not continue in the perfume business. When he was no longer a perfume dealer, the same man dreamt thathe did not have a nose. He was caught forging a signature and fled his own country. For anything that is lacking to a face disfigures and degrades it. And the face is the image of one's respectability and reputation. It is understandable that this man was disgraced.

During an illness the same man dreamt that he did not have a nose. He died not long afterwards, for the skull of the dead man has no nose. The first time, when he was a merchant the dream referred to his perfumes. The second time, when he was a citizen with full rights and franchises it referred to his reputation. The third time, when he was sick, it referred to his body itself. In this way, then, the same dream came true in three different ways for the same man’.

\section{Reference}

1 Artemidorus Daldianus. Oneirocritica. [The interpretation of dreams.] (translation and commentary by Robert J. White): 197-8. Noyes Press, 1975. 